\title{
Pamięć Limanowszczyzny Lekcja dialogu między literaturą międzywojenną a współczesną antropologią polonistyczną
}

\author{
The Remembrance of Limanowszczyzna \\ The Lesson of the Dialogue between Interwar Literature \\ and Contemporary Polish Language Anthropology
}

Summary: The aim of the publication The Remembrance of Limanowszczyzna. The Lesson of the Dialogue between Interwar Literature and Contemporary Polish Language Anthropology is to attract special attention to the significant role of Polish regional education carried out at the beginning of the 21st century. The focus of the discussion is on the subject indicated in the title, i.e. Limanowszczyzna (understood more broadly as the Sącz region). Reading the place has been presented from two main perspectives, which are mutually complementary: interwar literature (including the prose by Władysław Dunarowski) and contemporary anthropology. During Polish language lessons, they have been linked up in the axiological space of literary texts when the teacher together with the students open up to the dialogue between the past (cultural tradition of the region) and the present with reference to the future. The assumption has been made that reading the texts of culture and various contexts is meaningful when it leads to the understanding of man.

The considerations are in line with the modern humanistic concept in which reading the place is of great significance.

Key words: Limanowszczyzna, Władysław Dunarowski, little homeland, teaching Polish, regional education, Polish anthropology, reading the place 


\section{Współczesny paradoks: od „nie-miejsca” do tęsknoty za miejscami, które „rezonują tradycją"}

Szczególnego uroku dwudziestolecia międzywojennego dopatruję się m.in. w ponadczasowych założeniach edukacyjnych, które w centrum działań wychowawczo-dydaktycznych sytuowały znaczenie kultury małej ojczyzny. Podkreślano wtedy siłę więzi człowieka z rodziną, rodzeństwem, krewnymi, ale i konkretnym miejscem, akcentując dużą rolę tzw. silnej „więzi z przyrodzenia” i wychowania ${ }^{1}$. Współcześnie również wskazuje się na związki człowieka z miejscem. Nie idzie tutaj jednak o dowolny ,punkt na mapie”. O miejscu (stawaniu się miejsca) możemy mówić dopiero wtedy, gdy „zawiera w sobie historię lub utopię, zagrożenie lub bezpieczeństwo, tożsamość lub pamięć" ${ }^{2}$. Wydaje się, że w przeciągu prawie stu lat, choć zmieniał się charakter relacji człowiek-miejsce, wciąż niezmienne pozostało pragnienie odkrywania „na nowo" miejsca zastanego przez człowieka. Odwieczny dylemat: człowiek ma większy wpływ na miejsce czy miejsce „formuje” człowieka? - pozostawiam w dalszym ciągu nierozstrzygnięty. Proponowane rozwiązanie nie jest, rzecz jasna, wolne od ryzyka; przeciwnie - zakłada konieczność poszukiwań i głębszych przemyśleń. Nie wdając się w szczegóły na temat wyników wysiłku intelektualnego, zastosuję perspektywę dydaktyczną, w której najbardziej istotny jest sam proces myślenia znakomicie zilustrowany przez wybitnego humanistę — ks. Jana Twardowskiego:

Kiedy myślę i nic nie wymyślę, to sobie myślę, po co ja tyle myślałem, żeby nic nie wymyślić. Przecież mogłem nic nie myśleć i tyle samo bym wymyślił ${ }^{3}$.

W rozumowaniu przyjętym w toku dalszego wywodu nie zabraknie odniesień do miejsca wskazanego w tytule — Limanowszczyzny — z dwóch głównych perspektyw wzajemnie się dopełniających: literatury międzywojnia oraz antropologii współczesności ${ }^{4}$. Łączą się one w przestrzeni aksjologicznej tekstów

${ }^{1}$ E. Rosner: Rozważania wstępne. W: Regionalizm w nauczaniu języka polskiego w szkole średniej. Red. E. Rosner. Warszawa 1975, s. 15. Cyt. za: G. Piramowicz: Powinności nauczyciela... W: Komisja Edukacji Narodowej. Wybór źródet. Zebrał i oprac. S. Tync. Wrocław 1954, s. 287.

2 Zob. M. Lewicka: Psychologia miejsca. Warszawa 2012, s. 562.

${ }_{3}^{3}$ Zob. www.wyrwanezkontekstu.pl/literatura/kochamy-wciaz-za-malo-i-stale-za-pozno-cyta ty-z-ks-jana-twardowskiego/ [data dostępu: 1.08.2017].

${ }^{4}$ Prezentowany w artykule materiał został wygłoszony podczas ogólnopolskiej konferencji naukowej Proza dwudziestolecia międzywojennego z dzisiejszej perspektywy, zorganizowanej w krakowskim Uniwersytecie Pedagogicznym w dniach 2-3 marca 2017 roku. 
literackich, gdy na lekcjach języka polskiego wspólnie z uczniami otwieramy się na dialog pomiędzy przeszłością (tradycją kulturową regionu) i teraźniejszością z odniesieniem do przyszłości. W założeniu ogólnym czytanie tekstów kultury oraz rozmaitych kontekstów ma sens wówczas, gdy prowadzi do rozumienia człowieka (nawet, jeśli temu procesowi towarzyszy zasygnalizowane wcześniej ryzyko). Rozpoznanie modnych współcześnie koncepcji humanistycznych uzasadnia badania, w których jest znakomite miejsce dla czytania miejsca ${ }^{5}$.

Zanim rozpoczniemy lekcję dialogu z tradycją, warto zastanowić się, jak na początku XXI wieku w dyskursach naukowych postrzegana jest rzeczywistość społeczno-kulturowa z perspektywy związków między: pamięcią a nowoczesnością, człowiekiem a miejscem. Pomijając rozmaite kwestie pojęć pamięci, brak precyzji w ich definiowaniu, przyjmuję perspektywę antropologiczną, w której: „Pamięć [...] stała się świadectwem doświadczenia [...]”․ Oznacza to, że problematyka miejsca we współczesnym świecie łączy się z potrzebą indywidualizacji doświadczeń człowieka. Z pewnością w najnowszej humanistyce istotne są ustalenia francuskiego uczonego Marca Augé, autora dzisiaj powszechnie znanego i cytowanego, którego szczególnie interesuje punkt przecięcia pojęć tożsamości z miejscem zakorzenienia. Pokazuje on, jaka relacja zachodzi między „miejscami tożsamościowymi” a „nie-miejscami”, czyli przestrzeniami tranzytowymi, anonimowymi, „niczyimi”, takimi, jak: dworce kolejowe, lotniska, supermarkety. Jeśli przyjmiemy za słuszną diagnozę badacza antropologii w zakresie doświadczania dość złudnej rzeczywistości, której jesteśmy odbiorcami i uczestnikami, wówczas warto głębiej zastanowić się nad sensem wypowiadanych przez niego słów:

Świat hipernowoczesności nie jest dokładnie tym, w którym wydaje się nam, że żyjemy, ponieważ żyjemy w świecie, którego jeszcze nie nau-

${ }^{5}$ O aktualności wskazanej problematyki miejsca świadczy fakt, że podejmują ją badacze reprezentujący różne dziedziny naukowe. Reprezentatywnym przykładem współczesnych badań jest książka Marii Lewickiej Psychologia miejsca z bardzo obszerną bibliografią. Autorka odpowiada na pytanie badawcze, czy w psychologii jest miejsce dla miejsca, w tym sensie — czy psychologia może uczynić miejsce i związki człowieka z miejscem przedmiotem swojego zainteresowania? Korzysta przy tym z dorobku innych nauk, m.in. geografii humanistycznej oraz psychologii środowiskowej. Część jej badań dotyczyła także pamięci miejsca. Okazało się, że ,istotnym czynnikiem powiązanym $\mathrm{z}$ charakterem tej pamięci (etnocentryzmem bądź jego brakiem) były siła i charakter związku człowieka z miejscem”. Zob. M. Lewicka: Psychologia miejsca ..., s. 561. Polonistycznym rozpoznaniom miejsca rozumianego jako mała ojczyzna poświęciłam wiele dotychczasowych tekstów. Stanowią one próbę opracowania metodologicznych podstaw odbioru lektury ukierunkowanej na aksjologię miejsca. Zob. publikacje z nowoczesnej dydaktyki regionalnej, szczególnie zaś te powstałe w Pracowni Edukacji Regionalnej: www.filpolska.up.krakow.pl/ pracownia-edukacji-regionalnej.

${ }^{6}$ M. Saryusz-Wolska: Spotkania czasu z miejscem. Studia o pamięci i miastach. Fotografie J. Hohmuth. Warszawa 2011, s. 29. 
czyliśmy się oglądać. Powinniśmy nauczyć się od nowa myśleć o przestrzeni.

Zapośredniczony kontakt człowieka z miejscem, a nawet człowieka z człowiekiem, uzasadnia potrzebę studiowania kondycji współczesnego człowieka, uwikłanego w procesy globalne oraz wynikające z nich kulturowe szanse i zagrożenia. W przedmowie do wydania polskiego omawianej książki Wojciech J. Burszta zdecydowanie ostrzega przed różnymi napięciami ${ }^{8}$ oraz konsekwencjami życia w nowoczesności, gdy stwierdza:

O ile tradycyjna antropologia specjalizująca się w zjawiskach zakorzenionych w miejscach interesowała się wyobrażeniami o charakterze wspólnotowym, o tyle antropologia hiperrzeczywistości, postulowana przez Augé, będzie musiała zmierzyć się z problemem samotności jednostki w świecie nadmiaru przestrzeni, historii i pokusy standaryzowanej indywidualizacji doznań9.

Polski antropolog dostrzega we współczesnym sposobie traktowania miejsca dwie skrajności: z jednej strony wyodrębnia poczucie bezpieczeństwa; z drugiej zaś - ucieczki, połączonej z ciągłą pokusą mobilności. Szczególnie istotny dla dalszych rozważań wydaje się jego postulat, aby:

[...] W naszej niestałej epoce, w której zadaje się więcej pytań na temat „korzeni” niż na temat przyszłości, [...] przypominać, że mamy różnorodne korzenie i że nasza przyszłość jest otwarta ${ }^{10}$.

Reasumując, należy wskazać na osobliwy paradoks współczesności, objawiający się m.in. tym, że ,nie-miejsca rodzą tęsknotę za miejscami, które »rezonują tradycją«, są »opoką dla tożsamości«"11. Dzięki miejscom antropologicznym i wpisanym w nie trzem porządkom: identyfikacji, racjonalności

${ }^{7}$ M. Augé: Nie-miejsca. Wprowadzenie do antropologii hipernowoczesności. Thum. R. Chymkowski. Przedmowa W.J. Burszta. Warszawa 2012, s. 21.

8 Napięcia współczesności Wojciech J. Burszta rozumie za Markiem Augé następująco: „To jak żyją Francuzi, to tylko aspekt pewnej ogólniejszej sytuacji kulturowej, której sprawcą jest globalizacja świata. [...] To swoiste napięcie między zmysłem społecznym a wolnością indywidualną, potrzebą przynależenia a pielęgnowaniem autonomii podmiotowej, między zakotwiczeniem w konkretnym miejscu a dążeniem do tego, aby mobilność uczynić sensem udanego życia". Zob. W.J. Burszta: Samotność w świecie nadmiaru. Przedmowa do wydania polskiego. W: M. Augé: Nie-miejsca..., s. VIII-IX.

9 Ibidem, s. XIV.

${ }^{10}$ Ibidem.

${ }^{11}$ Zob. E. Dutka: Zapisywanie miejsca. Szkice o Śląsu w literaturze przełomu wieków XX $i$ XXI. Katowice 2011, s. 25. 
i historii możliwe jest — zdaniem Augé — tworzenie przez jednostkę i rozumienie własnej tożsamości ${ }^{12}$. W odróżnieniu od miejsc, nie-miejsca nie mają pamięci ${ }^{13}$. Miejsce przywodzi na myśl pewną zależność - nie istnieje ono bez mieszkańców, a zamieszkiwanie możliwe jest dzięki miejscu. Zakładam, podobnie jak Hanna Buczyńska-Garewicz, że warto przyjrzeć się ludzkim sposobom doświadczania miejsca ${ }^{14}$, nie zważając na kolejne wyzwanie. Ujawnia się ono w trakcie niespiesznych wędrówek po dawnych (międzywojennych) śladach antropologicznych, przekształconych lub zniszczonych przez czas i wymaga od człowieka żyjącego „tu i teraz” nowej interpretacji rzeczywistości utrwalonej w literaturze.

\section{$\mathrm{Ku}$ antropocentrycznej i antropologicznej metodyce polonistycznej}

Dydaktyka polonistyczna nie od dzisiaj wskazywała na potrzebę antropocentrycznych praktyk lekturowych ${ }^{15}$. Współcześnie dydaktyk-polonista korzystać może z najnowszych badań kulturowych, głównie antropologii literackiej, a także literaturoznawstwa empirycznego, opartego na świadectwach recepcji ${ }^{16}$. Rola nauczyciela języka polskiego, zainspirowanego szczególnie badaniami antropologicznymi, sprowadza się do analizowania i oceniania procesu rodzenia się sensu i nadawania znaczeń dziełom, z którymi w kontakt wchodzi uczeń.

${ }^{12}$ M. Augé: Nie-miejsca..., s. 34.

13 Polonista zapewne dostrzeże znaczenie przedrostka nie-, które zdaniem autorki: „,w połączeniu z pojęciami przestrzeni, miejsca i miasta bywa znacznie bardziej złożone, niż sugeruje to Augé”. Zob. M. Saryusz-Wolska: Spotkania czasu..., s. 148-152.

${ }^{14}$ Zob. H. Buczyńska-Garewicz: Miejsca, strony, okolice. Przyczynek do fenomenologii przestrzeni. Kraków 2006, s. 6.

${ }^{15}$ Upominali się o nie dydaktycy krakowscy: Anna Dyduchowa, Jan Polakowski, Zenon Uryga. Na temat założycieli nurtu antropocentryczno-kulturowego w dydaktyce literatury oraz współczesnych kontynuatorach pisałam więcej w książce: K. Pławecka: Przygotowanie polonistyczne uczniów wiejskich gimnazjów w perspektywie dalszego ksztatcenia (na przykładzie gminy Laskowa). Kraków 2013, s. 27-31. Zob. też B. Myrdzik: Zrozumieć siebie i świat. Szkice i studia o edukacji polonistycznej. Lublin 2006; D. Łazarska: Osoba ucznia w świadomości studentów polonistyki. O związu literaturoznawstwa z dydaktyka. Kraków 2015. „Fundamentem realizacji takich lekcyjnych projektów, które stawiają w centrum ucznia, a nie materiał i egzamin końcowy - musi być jednak zmiana stylu myślenia nauczycieli, także o sobie samych jako ludziach i jako wykonawcach zawodu" - upomina się współcześnie Danuta Łazarska. Eadem: Osoba ucznia w świadomości studentów polonistyki..., s. 93.

16 Zob. R. Nycz: Od teorii nowoczesnej do poetyki doświadczenia. W: Kulturowa teoria literatury 2. Poetyki, problematyki, interpretacje. Red. T. Walas, R. Nycz. Kraków 2012, s. 31-61. 
Do otwartej postawy wobec tekstu literackiego i działań potrzebnych dzisiejszej szkole zachęca szczególnie Marek Pieniążek:

Nauczyciel-antropolog nie będzie kontrolerem z góry założonego modelu komunikacji literackiej ani stróżem wysokoartystycznych funkcji, będzie natomiast kimś, kto literackość potraktuje pragmatycznie, nie wprowadzając ostrego rozdziału między życiem a literaturą, egzystencją a jej dyskursywnym kształtowaniem ${ }^{17}$.

Zgłoszonym propozycjom edukacyjnym towarzyszy założenie, że: po pierwsze - antropologia literacka w szkole przyczynia się do szybszego przekształcenia i wzbogacenia uczniowskiego kulturowego habitusu; po drugie świat ukazany z perspektywy mikrohistorii regionu szybciej i łatwiej może nabierać sensu w połączeniu $\mathrm{z}$ historią wielką, bez obawy o modelowanie ideo$\operatorname{logiczne}{ }^{18}$.

Przywołane założenia korespondują z pochwałą małych ojczyzn i małych historii oraz zaproponowanym przez Stanisława Burkota uzasadnieniem:

Mała historia bywa nawet ciekawsza od wielkiej, w której króluje przyciężkie uogólnienie — mówi o ludziach, a nie o procesach ${ }^{19}$.

W tekstach będących zapisem indywidualnych doświadczeń, powiązanych z konkretnymi osobami, miejscami, zdarzeniami, interesujące (nie tylko) z perspektywy ucznia może być właśnie współtworzenie własnej mikrohistorii ${ }^{20}$ re-

${ }^{17}$ M. Pieniążek: Uczeń jako aktor kulturowy. Polonistyka szkolna $w$ warunkach ptynnej nowoczesności. Kraków 2013, s. 92.

18 Powodów, dla których warto pielęgnować tradycje regionalne np. w muzyce, stroju, obyczaju itd., jest wiele. Niektóre z nich podaje miłośnik Sądecczyzny: „Od czasu do czasu w różnych dyskusjach o regionalizmie można usłyszeć sceptyczne czy wręcz ironiczne uwagi, że to zaściankowość, prowincjonalizm itp. Zgadzam się z Leszkiem Żulińskim, który w kontekście książki J. Kwiek-Osiowskiej: Ziemio moja sqqecka... Antologia poezji i prozy. Kraków 1991 napisał: »Podsycanie miłości do jakiegokolwiek regionu jest w gruncie rzeczy działaniem antymitotwórczym: uczy ludzi patrzeć na własną skibę ziemi, przywiązuje do małej ojczyzny, która przecież jest najbardziej konkretną i naturalną wartością, bo ojczyzna to przede wszystkim region [...] «". Jest zatem w słowach Żulińskiego wiele racji. Patriotyzm w skali makro należy budować na patriotyzmie w skali mikro. Zob. B. Faron: Powrót do korzeni. Kraków 2000, s. 10.

19 S. Burkot: Pochwała małych ojczyzn i małych historii. „Małopolska”. T. 7. Red. E. Chudziński. Kraków 2005, s. 312.

${ }^{20}$ Ewa Domańska podkreśla wzrost popularności tzw. mikrohistorii, tj. subiektywnie konstruowanych opowieści o przeszłości, będących również sposobem wytłumaczenia aktualnej rzeczywistości. Zob. E. Domańska: Mikrohistorie. Spotkania w międzyświatach. Poznań 2005, s. 170 - 288. W tym kontekście uwagę przykuwa zamysł autorki, dla której pisanie książki stało się próbą ,połączenia świata, w którym żyję, ze światem, który żyje we mnie”. Ibidem, s. 8. 
gionu poprzez spotkanie z doświadczeniem kulturowym, w socjosferze i przestrzeni jego mikroświata, dzielnicy ${ }^{21}$. Ich dobrą egzemplifikacją jest wydana współcześnie książka Powrót do korzeni, którą można jednocześnie zaliczyć do nurtu literatury małych ojczyzn ${ }^{22}$. Chwilami głęboko wzruszające, niezwykłe świadectwa dokumentują serdeczną pamięć o najbliższych, rodzinie, najgłębszych przeżyciach (śmierci matki), całej Sądecczyźnie ${ }^{23}$. Kolejny ważny powód przywołania tej książki wiąże się z potrzebą utrwalenia międzywojennego przesłania, które Bolesław Faron ${ }^{24}$ przyjął za znaczące dla swojej (auto)biografii i które (jak sądzę) nic nie straciło na aktualności; zapewne dlatego, że sformułował je znakomity „piewca Gorców i Podhala” 25 - Władysław Orkan. We Wskazaniach dla synów Podhala z 1922 roku pisał on:

${ }^{21}$ Zob. M. Pieniążek: Uczeń jako aktor kulturowy..., s. 259-290. Autor podaje ciekawe przykłady twórczości objaśniającej przeszłość i pomagającej artykułować dzisiejszość Olkusza oraz okolic.

22 Znawca międzywojnia z pewnością dostrzeże analogię pomiędzy rangą miejsc najpierwszych człowieka tzw. korzeni a świadomością rangi dziedzictwa małej ojczyzny w edukacji, o której pisał pięknie Artur Górski w 1918 roku: „Nie ma dobrego wykształcenia opartego na teoretycznym poznawaniu świata. Takie wychowanie »nie puszcza korzeni w duszę«, bo nie pokazuje młodemu człowiekowi, dokąd pójść i jak w tej drodze zdobytej wiedzy używać”. Zob. A. Górski: Na nowym progu. Warszawa 1918, s. 22. Za: Z. Budrewicz: Tradycje i wspótczesność regionalizmu edukacji polonistycznej. W: Region i edukacja. Literatura - kultura - społeczeństwo.

Red. Z. Budrewicz, M. Kania. Kraków 2006, s. 27.

${ }^{23}$ Współcześnie Sądecczyzna rozumiana bywa jako dawne województwo nowosądeckie, do którego zaliczyć należy powiat limanowski. Warto jeszcze zauważyć, że w tytułach międzywojennych pism sądeckich umieszczano przymiotnik ,,podhalański”, np. „Głos Podhala”, ,Tygodniowy Kurier Podhalański”, „Wieści z Podhala” itd., chociaż granice Podhala nie są jednoznacznie określane przez geografów i etnografów, a zwłaszcza mieszkańców regionu. Zob. K. Pławecka: Limanowa w świetle międzywojennej prasy nowosądeckiej. „Rocznik Sądecki”. T. XXXII. Red. F. Kiryk. Nowy Sącz 2004, s. 209-221. Przywołana przestrzeń geograficzna, tj. południowo-wschodnia Małopolska, prowadzi do „topografii”, czyli sposobów istnienia (doświadczenia) w utworach literackich konkretnej okolicy. Zob. E. Dutka: Zapisywanie miejsca..., s. 5.

${ }^{24} \mathrm{Z}$ perspektywy współczesnego wychowania humanistycznego i dyskursów skupionych wokół procesu kształtowania tożsamości kulturowej ucznia za znaczące należy uznać wystąpienie przywołanego już Bolesława Farona, ówczesnego ministra, który dostrzegał potrzebę łączenia tradycji ze współczesnością. Podkreślał on: „Świadomość młodego Polaka kształtują nie tylko nowe doświadczenia życiowe, lecz i przeszłość, tradycja. Pojmuję tradycję nie tylko jako zespół dawnych ksiąg, do których nieprzedawnionego uroku wracam i których mądrość i piękno podziwiam. Tradycja - to również zrozumienie swego miejsca w rozwoju narodu i ludzkości, to zarazem źródło inicjacji do własnej aktywności w nowej sytuacji narodu i świata. Tak pojęta tradycja nie odsuwa mnie od teraźniejszości, przeciwnie, narzuca pogłębiony kontakt z dniem dzisiejszym”. Wystapienie Ministra Oświaty i Wychowania - prof. dra hab. Bolesława Farona. „Polonistyka” 1983, nr 7, s. 491.

${ }^{25}$ Zob. B. Faron: Władystaw Orkan i Beskid Ślaski. W: Wokół Władysława Orkana. Aspekty literackie, kulturowe i medialne. Red. B. Faron, współpraca A. Ogonowska. Kraków 2011, s. 27. 
Nie przecinaj korzeni łączących cię z rodzinną ziemią, choćbyś na końcu świata się znalazł. [...] A przede wszystkim miej charakter! ${ }^{26}$.

Ponadczasowe przesłanie „dumaca z Gorców” prowadzi bezpośrednio do biografii Władysława Dunarowskiego oraz jego twórczości, będącej kolejną egzemplifikacją literackiego powrotu do korzeni, przykładem opisania miejsca bliskiego doświadczeniu autora.

Pomijając kwestie różnic ${ }^{27}$, omawianych pisarzy łączy pochodzenie chłopskie, a także miejsce narodzin, czyli — powiat limanowski. Pierwszy z nich urodził się w 1875 roku w Porębie Wielkiej (zm. 1930 w Krakowie), drugi zaś w miejscowości Jaworzna — w 1902 roku (zm. 1987 w Bydgoszczy) ${ }^{28}$. Obydwaj, dzięki zdobytemu w trudnych warunkach wykształceniu, osiągnęli awans kulturalny i społeczny. O ile sami nie mogli mieć wpływu ani na pochodzenie, ani też na miejsce, w którym przyszli na świat, o tyle spotkania w książnicy limanowskiej (obecnie bibliotece im. Władysława Dunarowskiego), wówczas starszego pisarza z bardzo młodym jeszcze przyszłym prozaikiem, wydają się być znaczące, zwłaszcza dla twórczości Dunarowskiego ${ }^{29}$. Imieniem Władysław posługiwali się obydwaj, chociaż znawca biografii Orkana zauważy zamianę (z Franciszek Ksawery). Elementów podobieństwa doszukuję się w podejmowa-

${ }^{26} \mathrm{Z}$ uniwersalnego przesłania Władysława Orkana mogą czerpać także współcześni nauczyciele, którym udziela fachowej, mądrej porady: „Jeśli będziesz profesorem [nauczycielem K.P.] — bądź wychowawcą. W najwyższym tego słowa znaczeniu. Kochaj młodzież jak swoje dzieci”. Zob. B. Faron: Powrót..., s. 24. Zob. też K. Pławecka: Recenzja książki Bolesława Farona „Powrót do korzeni”. „Nowa Polszczyzna” 2001, nr 1, s. 70.

${ }^{27}$ Ze względu na omawiane miejsce w literaturze - Limanowszczyznę — skupiam się na elementach wspólnych dla obydwu pisarzy, chociaż mam świadomość różnic, które akcentował Zdzisław Mrozek, tj.: „[...] Dunarowski wykorzystał niektóre dawniejsze doświadczenia literackie z kręgu tematyki wiejskiej (Władysław Reymont, Władysław Orkan), zrezygnował jednak z etnograficznej egzotyki i »bajecznie kolorowych« (Sewer) pejzaży na rzecz psychologicznej wierności postaci i realnego obrazu obyczajów lokalnej społeczności”. Zob. Z. Mrozek: Władysław Dunarowski. „Fakty” 1986, nr 3. Zob. też W. Orkan: Komornicy i opowiadania wybrane. Wyboru dokonał i posłowiem opatrzył B. Faron. Warszawa 1975, s. 265-266.

${ }^{28} \mathrm{Na}$ temat śladów (auto)biograficznych Władysława Dunarowskiego w regionie limanowskim, jego związków z ziemią limanowską i Bydgoszczą oraz dość obszernego dorobku prozatorskiego piszę więcej w: K. Pław ecka: „Pomiędzy kultura a ziemiq”. Od świata globalnego do lokalnego na przyktadzie literatury ,stad”. „Annales Universitatis Paedagogicae Cracoviensis. Studia ad Didacticam Litterarum Polonarum et Linguae Polonae Pertinentia VIII". Red. M. Szymańska, M. Pieniążek. Kraków 2017, s. 195-212.

${ }^{29}$ Halina Matras, wieloletnia dyrektorka Biblioteki Publicznej w Limanowej, tak oto pisze o niezwykłych, limanowskich spotkaniach: „,[Dunarowski - K.P.] uczęszczał w Limanowej do starszych klas szkoły podstawowej. Bardzo często przebywał w domu Beków przy ul. Słonecznej w Limanowej, spotykając się tam m.in. z Żuławskim i Orkanem. Jako kilkunastoletni chłopiec korzystał ze zbiorów bibliotecznych w czytelni prowadzonej przez Beków w Limanowej”. Zob. H. Matras: Dunarowski Władysław, 21 III 1982 roku. [Maszynopis], s. 3. 
nej przez nich problematyce, której urokom, zdaje się, ulegli obydwaj, chociaż opisywali głównie problemy egzystencjalne: biedę, głód, niedolę mieszkańców podhalańskich wsi. Zapisy te współcześnie zyskują status świadectwa społeczno-ekonomicznej sytuacji wsi końca XIX i początku XX wieku. Piewcy swojej ziemi dokonali mikroanalizy środowiska wiejskiego, wcielając się w rolę reporterów, którzy szczegółowo rejestrują obrazy życia wiejskiego (procesy tam zachodzące), zachowując przy tym własny styl wypowiedzi literackiej. W pewnym sensie po raz kolejny łączy ich jeszcze jedno - sentyment, na który zwrócił uwagę badacz literatury, gdy w Posłowiu do twórczości Orkana pisał:

Nie zdobył się natomiast autor „Nowel” na postulowany przez naturalistów „obiektywizm badacza”. Raz po raz w komentarzu autorskim ujawnia swój sentyment do krainy kęp i jej mieszkańców ${ }^{30}$.

W dalszym toku wywodu spróbuję dowieść, że twórczość Dunarowskiego, chociaż nie tej miary co Orkana, stwarza ,możliwości głębszego spojrzenia na innego człowieka i siebie samego"31 poprzez miejsce, w którym żyje.

\section{Od międzywojennej literatury do człowieka}

Nazwisko Dunarowskiego (zwłaszcza jego powojenne publikacje) najczęściej wiązano z tzw. nurtem chłopskim ${ }^{32} \mathrm{w}$ literaturze, chociaż jego twórczość, obejmująca chronologicznie trzy etapy historyczne: dwudziestolecie międzywojenne, okres okupacji, lata powojenne, dobrze łączy się z problematyką regionalną i tym samym zasługuje na zaliczenie jej do tzw. nurtu małych ojczyzn.

Dodatkowo warto w tym miejscu uświadomić sobie, że ambicją twórców literatury regionalnej, w tym zapewne pisarza Limanowszczyzny, było wprowadzenie głosu regionu do ogólnego wielogłosu kultur. Międzywojenny regionalizm literacki kontynuował regionalizm młodopolski, przystosowany do nowej

${ }^{30}$ Zob. B. Faron: Postowie. W: W. Orkan: Komornicy i opowiadania..., s. 263-264.

${ }^{31}$ J. Polakowski: Idee dydaktyki podmiotowej $w$ podstawowych problemach ksztatcenia literackiego (nurt antropocentryczno-kulturowy). W: Podmiotowy wymiar szkolnej polonistyki. Red. Z. Uryga. Kraków 1998, s. 18.

${ }^{32}$ Według Stanisława Burkota nurt chłopski to literatura tworzona przez wychodźców ze wsi, przez nową generację naszej inteligencji. Awans społeczny owej grupy prowadził przez szkoły średnie i studia wyższe [...]. W ich twórczości do rangi podstawowego mitu urasta poczucie związku ze środowiskiem, z którego się wyszło. Zob. S. Burkot: Proza powojenna 1945-1987. Warszawa 1991, s. 81. 
rzeczywistości niepodległego państwa ${ }^{33}$. Powstają wówczas nowe grupy literackie głoszące pochwałę regionów. W polityce kulturalnej regionalizm (współcześnie również) bywa przyjmowany jako „wartość źródła” bądź odrzucany jako „kompleks pochodzenia” ${ }^{34}$. W południowej Małopolsce pochwałę regionu beskidzkiego prowadzi m.in. grupa poetycka Czartak programowo antyurbanistyczna i antywarszawska, nastawiona na obieg ogólnopolski. W 1925 roku na łamach czasopisma deklarowano postawę franciszkańskiej radości połączoną z afirmacją gór:

Z najwyższych szczytów tej Republiki górskiej chcemy rozsiewać światło w myśl odwiecznej prawdy, że wszelka radość idzie z gór ${ }^{35}$.

Tematyka krainy górskiej, bliskie sąsiedztwo geograficzne Podbeskidzia z Limanowszczyzną — łączą twórczość Czartaka z Dunarowskim; różni jednak odmienna, mniej „radosna” optyka człowieka i gór przyjęta przez pisarza rodem z ziemi limanowskiej. Być może punkt widzenia Dunarowskiego wynikał $\mathrm{z}$ dystansu, który dzielił miejsce urodzenia pisarza od miejsca zamieszkania, albo też z umiejętności analitycznych prozaika z autopsji znającego warunki życia na wsi (Limanowszczyźnie) i w mieście (Bydgoszczy), gdzie zakorzenił się, pracował aktywnie, współtworząc środowisko inteligencji humanistycznej Pomorza i Kujaw. Utrzymywał i pielęgnował więzi „z przyrodzenia”, których, pomimo znacznego oddalenia, nie zerwał. Przeciwnie: „krajobraz dzieciństwa” sytuował w centrum swojego świata. Problematyce małej ojczyzny skupionej wokół krewnych, rodaków z terenów niegdysiejszej Kamery (będącej własnością Klarysek Starosądeckich) i ziemi limanowskiej poświęcił swój dorobek literacki, pozostając mu wiernym aż do śmierci ${ }^{36}$.

33 Trzeba doprecyzować za Elżbietą Rybicką, że regionalizm polski (i nie tylko) już w dwudziestoleciu został związany z polityką miejsca, jednak tzw. literatura małych ojczyzn wydaje się najważniejszym i najbardziej znamiennym zjawiskiem dla lat dziewięćdziesiątych XX wieku. Zob. E. Rybicka: Geopoetyka. Przestrzeń i miejsce we współczesnych teoriach i praktykach literackich. Kraków 2004, s. 325-349.

${ }^{34}$ Zob. R. Sulima: Głosy tradycji. Warszawa 2011, s. 98-103 (szczególnie rozważania pt.: Mity polskie i mity ludowe).

${ }^{35}$ E. Kuźma: Regionalizm. W: Stownik literatury polskiej XX wieku. Red. A. Brodzka et al. Wrocław-Warszawa 1992, s. 928. Twórcy skupieni wokół grupy literackiej Czartak, zwanej też Zborem Poetów Beskidzkich, opiewali piękno gór, propagowali umiłowanie przyrody i beskidzkiego krajobrazu, choć w swych utworach przedstawiali życie prostych ludzi, zespolonych poprzez pracę z ziemią; ich codzienność trudną i biedną, ale w jedności z naturą. Cykl ballad Emila Zegadłowicza Powsinogi beskidzkie do dzisiaj budzi zachwyt czytelników. Zob. www.mapakultury.pl [data dostępu: 1.08.2017].

${ }^{36}$ W Limanowskiej Bibliotece im. Władysława Dunarowskiego podziwiać można liczne medale i odznaczenia przyznane pisarzowi, wystawę jego publikacji, a także narzędzia pisarskie, tj. maszynę do pisania oraz szklaną kulę, która chroniła ręce pisarza przed zbytnim przemęczeniem. 
W kreowaniu literackiego obrazu podgórskiej krainy (usytuowanej w opozycji przestrzennej wieś-miasto) zwraca uwagę ponury, mówiąc językiem samego ks. Józefa Tischnera, dramatyczny wymiar doświadczenia człowieka swoisty genius loci, skupiający przede wszystkim trudy egzystencji naznaczonej przez czas i niekorzystne uwarunkowania społeczne ${ }^{37}$. W tej zrodzonej z bólu filozofii ludzkiej można dostrzec integralny związek między doświadczeniem sceny a doświadczeniem człowieka. W refleksji filozoficzno-antropologicznej owa scena staje się miejscem dramatu, o którym znakomity znawca człowieka i gór pisze następująco:

Świat ogólny ludzkiego dramatu to najpierw rzeczywistość sceny. Scena jest miejscem akcji dramatycznej. Na scenę składają się: rzeczy, przedmioty, krajobrazy, a także uobecniani w doświadczeniach typu intencjalnego inni ludzie. [...] Przedmioty, rzeczy, ludzie są zawsze gdzieś, przywiązani jakoś do miejsc, w których pozostają w bezruchu bądź w pewnym stopniu poruszają się. [...] Człowiek jest częścią owego krajobrazu. Gdy zniknie z niego, wspomnienie krajobrazu, w którym go widywaliśmy, przywoła jego obecność. Brak człowieka wśród rzeczy, pomiędzy którymi bywał, rodzi wrażenie, że scena jest pusta $^{38}$.

Przyjęty za Tischnerem kierunek dramatycznej interpretacji egzystencji ludzkiej, rozpiętej między życiem a śmiercią, sprzyja interesującej refleksji antropologiczno-kulturowej na temat ludzi i miejsc opisanych przez Dunarowskiego. W tej smętno-realistycznej oprawie prezentowanego świata nie ma żadnej „przesady”; jej miejsce zajmuje dokument, niczym fotografia, zaświadczający o prawdziwości opisywanego świata. Na potwierdzenie tego stanowiska przy-

${ }^{37}$ Mała ojczyzna Dunarowskiego w pewien sposób zawęża się do ojczyzny prywatnej przeżywanej w rodzinno-sąsiedzkim otoczeniu, podobnie jak ojczyzna regionalna śląskiego powojennego twórcy Jana Goczoła. Znawczyni kultury śląskiej interesująco objaśnia specyfikę ,zatrzymania krainy w wartościach”: „Plemienna odmienność lokalnej kultury, sprzyjała obrazowaniu regionu w perspektywie zakorzenienia. Poeta, sytuując się w centrum śląskości, za jakie miał swój „matecznik” — rodzinną wieś Rozmierz — mógł głębiej wchodzić »w-człowieka«, »dokładniej w-słuchiwać się w niego«, prowadzić obrachunek ze swojskim środowiskiem i stanem kultury regionu, by odnowić zadomowienie rodaków". Zob. K. Kossakowska-Jarosz: Opolszczyzna prywatna w pisarskim doświadczeniu Jana Goczoła. W: Geografia wyobrażona regionu. Literackie figury przestrzeni. Red. D. Kalinowski, M. Mikołajczak, A. Kuik-Kalinowska. Kraków 2014, s. 269.

38 J. Tischner: Filozofia dramatu. Kraków 2012, s. 178-179. Zob. też P. Sporek: Pojęcie sceny w przestrzeni aksjologicznej dialogu. Edukacyjny wymiar refleksji filozoficznej Józefa Tischnera. „Annales Universitatis Cracoviensis. Studia ad Didacticam Litterarum Polonarum et Lingua Polonae Pertinentia VI”. Red. P. Kołodziej, J. Waligóra. T. 6. Kraków 2015, s. 8-22. Podkr. - K.P. 
toczę fragment przyjacielskiej korespondencji pisarza z polonistką Zofią Oleksówną (1905-1966), która ze znawstwem konstatuje:

Władku [...]

Od 1914-1964 uwieczniłeś jak na fotografii, co się działo na wsi, jak się pracowało, jak się myślało, co się czuło i to jest największa zasługa, czego nie ma w twórczości Orkana i Reymonta, bo żyli w innych czasach. Specyficzna epoka, specyficzne czasy, ogromne przemiany prosiły się o uchwycenie, uwiecznienie ${ }^{39}$.

Jako zachęta i jednocześnie pomoc w zrozumieniu twórczości międzywojennej pisarza posłużyć mogą jego indywidualne, subiektywne wypowiedzi skupione wokół aksjologii miejsca, stanowiące dowartościowanie „ojczyzny najpierwszej”, mieszkańców rodzinnej wioski i wartości tam nabytych. Wspó1cześnie w epoce globalizacji (i modnej mobilności) wybrzmiewają one dość oryginalnie. Ujmują szczerością, prostotą; bezpośrednio ujawniają przywiązanie pisarza do starej wsi, zapamiętanej jeszcze z czasów dzieciństwa:

To prawda, że piszę o wsi, a dlaczego ją wybrałem? Częściowo wpłynął na to fakt, że tam, na Podkarpaciu, uczyłem się obserwować ludzi i ich życie, a nawet więcej, uczyłem się tam przeżywać. Sam przecież byłem jednym z nich. I do dziś pozostałem wierny Limanowszczyźnie — jeżdżę do Ujanowic każdego lata ${ }^{40}$.

Wiem, że zaliczany jestem w poczet pisarzy tzw. nurtu literatury wiejskiej (nie jest to najszczęśliwsze określenie!), ale ja sam nigdy nie wydzielałem pisania o wsi jako coś odrębnego w całym pisarstwie... Ja po prostu piszę o ludziach, a że akurat mieszkają na wsi? Interesują mnie ludzkie problemy, to co się dzieje wokół człowieka i to, co przeżywa on w swojej głębi.

${ }^{39}$ Listy Zofii Oleksówny do Dunarowskiego. Nowy Sącz, 12 XI 1965. Wydruk komputerowy listów otrzymałam od księdza Józefa Treli, emerytowanego proboszcza parafii Żmiąca, jednocześnie miłośnika i dokumentalisty kultury opisywanego regionu.

${ }^{40}$ E. Jurkiewicz: Literacki świat Władysława Dunarowskiego. Praca magisterska napisana na seminarium literatury polskiej pod kierunkiem dra Zdzisława Mrozka. Wyższa Szkoła Pedagogiczna w Bydgoszczy. Bydgoszcz 1988, s. 144, 145. Korzystałam z kopii pracy dostępnej w limanowskiej bibliotece. Moją szczególną uwagę zwrócił wywiad autorki z pisarzem (rozdział szósty), skąd zaczerpnęłam trzy cytaty. Warto dodać, że Dunarowski wrócił z Bydgoszczy do rodzinnych stron w okresie okupacji, aby wspólnie z miejscową inteligencją (pod kierunkiem Oleksówny) prowadzić tajne nauczanie na ziemi limanowskiej. Tę konspiracyjną działalność edukacyjną można współcześnie odczytywać także w kategoriach szczególnego przywiązania pisarza do małej ojczyzny. 
Najwięcej nowel poświęciłem właśnie tej starej wsi z okresu dwudziestolecia międzywojennego, bowiem była to wieś jaką znałem, lubiłem i rozumiałem.

W mojej wsi Jaworzna nauczyłem się szacunku do pracy. Nikt mi tego nie odbierze. [...] Osobiście jestem zadowolony, iż napisałem sporo opowiadań, które ukazały cząstkę prawdy o przedwojennej wsi. Wstydzić się nie muszę $e^{41}$.

Chcę, żeby to, co piszę było prawdziwe, z ludzkiego serca wyciśnięte. Ale to nie wszystko. Musi być jeszcze piękne ${ }^{42}$.

W refleksji nad człowiekiem i miejscem (także w literaturze) trzeba postawić pytanie: jak w świecie literackim przyjęto twórczość debiutującego w międzywojniu pisarza ziemi limanowskiej? Najczęściej pojawia się informacja na temat dobrego przyjęcia dwóch publikacji autora. Najpierw o noweli Złodziej kwiatów z 1927 roku pisano:

Ukazała się [ona - K.P.] w luksusowym miesięczniku Gebethnera i Wolfa „Naokoło Świata”. Za ten utwór otrzymał nagrodę wydawnictwa „Rój”. W 1935 roku Polska Akademia Literatury przyznała Dunarowskiemu, jako młodemu twórcy, „Srebrny Wawrzyn”. Zadowolony z wyróżnienia, nie przyjął go jednak. Protestował w ten sposób przeciw trudnej sytuacji młodego pisarza rodem ze wsi ${ }^{43}$.

Następnie książkę pt. Ludzie spod miedzy opublikowano w 1939 roku (tuż przed wybuchem wojny). Na tle większości źródeł podających lakoniczne informacje na ten temat (najczęściej datę publikacji i tytuł, mylną kwalifikację „powieśćc" ${ }^{4}$, zamiast zbór opowiadań) znowu pojawia się zapis z chwalebnymi recenzjami:

${ }^{41}$ Z. Jędrzyński: Władysława Dunarowskiego pisarskie przesłanie. „Gazeta Pomorska” 1988, nr 11, s. 3.

${ }^{42}$ G. Nowicka: Wnikanie w los człowieka. „Gazeta Pomorska” 1983, nr 23, s. 5. Podkr. K.P.

${ }^{43}$ Bydgoski stownik biograficzny. T. 5. Red. J. Kutta. Bydgoszcz 1998, s. 29.

44 „W 1939 wydał powieść Ludzie spod miedzy” odnotowano W: Literatura polska XX wieku. Przewodnik encyklopedyczny. T. 1. Red. A. Hutnikiewicz, A. Lam. Warszawa 2000, s. 136. Lub też: „Powieść została przyjęta dobrze, a Dunarowski rozwijał później zarysowane tu elementy stylu, właśnie owego surowego" - stwierdza Piotr Kuncewicz. P. Kuncewicz: Agonia i nadzieja. Literatura polska od 1939. T. 2. Warszawa 1993, s. 363. Jeszcze inni badacze literatury wskazują na zbieżność tematyki w obrębie książki, co może sugerować podobieństwo zbliżone do powieści. Przyjmuję za wiarygodne wyjaśnienie znawcy twórczości Dunarowskiego, Zefiryna Jędrzyńskiego: „Debiut — to tom opowiadań, a nie powieść”. Zob. Z. Jędrzyński: Władysława Dunarowskiego pisarskie... Jędrzyński znał osobiście Dunarowskiego i jego literackie upodobania. 
W 1939 roku „Rój” opublikował pierwszą książkę Dunarowskiego pt. „Ludzie spod miedzy”. Książka miała znakomitych recenzentów (m.in. Karol Ludwik Koniński, Zygmunt Lichniak, Włodzimierz Pietrzak) i równie znakomite recenzje. Kolejne jej wydania ukazały się w 1947 i $1987^{45}$.

Międzywojenna publikacja Ludzie spod miedzy (z 1939 roku) została wznowiona $\mathrm{w}$ roku 1987, a zatem była ona publikacją ostatnią, zamykającą poczet ok. dwudziestu tomów opowiadań i powieści pisarza. Tytuł książki nasuwa skojarzenie z obrazem świata człowieka rekrutującego się z nizin społecznych, oddzielonych od świata przysłowiową graniczną miedzą. Nazwa łączy się także z miejscem urodzenia pisarza oraz dzieciństwem spędzonym „u Kiławca pod miedzą" ${ }^{\prime 46}$ (okolice cmentarza parafialnego) w rodzinnej Jaworznej.

W centrum dalszych rozważań pozostanie opisany przez Dunarowskiego region (w wyborze), będący miejscem wydarzeń sprzed prawie stu lat. Jest on istotny ze względu na specyficzne uwarunkowania terenów podgórskich oraz opowiadane historie ludzkie. W ujęciu ogólnym - nie ukazują one związku chłopa z ziemią w kategoriach mitu, w żaden sposób nie przywodzą na myśl wsi „sielskiej” z pięknymi krajobrazami. Kraina opisywana przez Dunarowskiego, $\mathrm{z}$ doświadczenia znającego trudne realia wiejskie, prowadzi w dużym stopniu do demitologizacji, niekiedy negowania rzeczywistości, w której ziemia bywa, zdaniem Andrzeja Boryckiego, „niezbędnym czynnikiem przetrwania, a jednocześnie przekleństwem chłopskiego losu, źródłem zła i cierpień" ${ }^{37}$.

Literacka przestrzeń Beskidu Wyspowego wypełniona została konkretnymi podgórskimi miejscowościami. Zaliczymy do nich następujące wioski: Jaworzną, Laskową, Kamionkę Małą, Ujanowice, Żbikowice, ulokowane w pobliżu miast: Limanowej i Nowego Sącza. Bohaterowie są częścią opisywanego świata, najczęściej mieszkańcami wspomnianego regionu limanowskiego. Ich ogólny (choć zapewne wart osobnego opracowania) obraz można by „,namalować” słowami tak: uprzywilejowani mężczyźni (dominuje patriarchat, stąd mężczyzna czuł się panem losu, ponieważ ,jego zawsze święte”); niedoceniane kobiety, przeciążone pracą i nadmiarem obowiązków (w domu, przy dzieciach i na roli); gromady dzieci, głodnych, nieodpowiednio odzianych, zmuszanych do pracy fizycznej ponad siły; bardzo ambitni uczniowie, którzy przy poświęceniu całej rodziny kontynuują naukę w mieście; samotni, smutni, starcy.

Nie licząc miejsc migracji (np. do Krynicy, Rabki, Zakopanego) i emigracji zarobkowych ,za chlebem” (do Ameryki), bohaterowie poruszają się po ziemi limanowskiej pieszo; codziennie, gdy wypełniają obowiązki gospodarskie; co

${ }^{45}$ Bydgoski stownik biograficzny..., s. 29.

46 Informacje na temat miejsca urodzenia pisarza przekazała mi (podczas rozmowy telefonicznej) Antonina Zelek z Jaworznej, niezwykła znawczyni dziejów swojej rodzinnej wioski.

${ }^{47}$ A. Borycki: O pisarstwie Władystawa Dunarowskiego. W: Nad Dunajcem pachnie siano. Wybór opowiadań. Gdańsk—Bydgoszcz 1978, s. 258. 
niedzielę idą do kościoła; w ciągu tygodnia, gdy ustają prace w polu, zachodzą na wieś do sąsiadów najczęściej ,za potrzebą" lub w celach towarzyskich; odwiedzają chorych, wymieniają się nowinami, narzekają na swój nieszczęsny los.

Zarejestrowany przez Dunarowskiego obraz świata sprzed stu lat niczym nie przypomina współczesnych wygodnych sposobów przemieszczania się z miejsca na miejsce. Piesze wyprawy do Limanowej lub Nowego Sącza wiązały się wówczas z licznymi trudnościami i pokonywaniem przeszkód podczas przepraw przez góry (Miejską Górę), lasy (na skróty), złowrogie paryje, miejscowe, rwące potoki, rzeki: Łososinę i Dunajec. Opuszczanie orbis interior, czyli świata własnego, niewątpliwie znanego, wiązało się z przedostawaniem się do orbis exterior, tj. świata obcego, nieznanego. Bohaterowie udają się więc do „Starygo Miasta"48, rzadziej na odpust (np. do Kamionki ${ }^{49}$ ), co z kolei oznaczało wejście do świata o odmiennym od zwykłego porządku ${ }^{50}$. Towarzyszyło mu zmienione (w porównaniu z codziennym) zachowanie połączone ze szczególną troską o odświętny ubiór. Jesteśmy oto świadkami humorystycznej sceny, gdy Maryna Micionka przyszła pożyczyć od Hanki „chustki na odzianie”, a wcześniej od Tereski z Koszar wypożyczyła „zapaskę i buty”. Jej wyjściu do „obcego" kościoła towarzyszy radość z odświętnego wyglądu („Wyparaduję się, że strach! Już lecę, bo idę do Kamionki") wynikającą z niecodziennej okazji do spotkania się z ludźmi (kontaktu face to face) oraz potrzeby „wygadania się za cały tydzień" ${ }^{51}$.

Wyprawy do pobliskich miejscowości planowano niegdyś bardzo szczegółowo. Jako przykład niech posłuży wyprawa na miejski jarmark do Limanowej połączona z załatwianiem spraw urzędowych, ,aby się nie nazywało, że po próżnicy nogi tłukł i czas mitrężył" 52 — powie jeden z bohaterów. Prezentowany punkt widzenia wynika zapewne z pragmatyzmu wiejskiej ludności i tzw. ekonomii czasu, ale też przekonania, że życie i praca na wsi są dużo trudniejsze niż w mieście, gdyż wymagają ciągłego nakładu pracy. Za niezwykle atrakcyjny dla miejskiego stylu życia uważano tzw. czas wolny; przeciwieństwo nieustającej, wręcz niewolniczej pracy w domu i obejściu ${ }^{53}$. W rozpoznaniu światopoglą-

48 W. Dunarowski: Żywe i kamienne anioły. W: Ludzie spod miedzy. Bydgoszcz 1987, s. 87. Skrupulatność badawcza każe odnotować różnice w poszczególnych wydaniach książki Dunarowskiego Ludzie spod miedzy. W pierwszym wydaniu z 1939 roku pojawiła się tylko ciągła numeracja poszczególnych rozdziałów: Rozdziat I, Rozdział II..., Rozdział XX. W kolejnych wydaniach książki z lat 1947 oraz 1987 podano tytuły poszczególnych części. Dalsze cytaty zaczerpnięto z publikacji datowanej na 1987 rok (z uwagi na możliwość jej wypożyczenia), stąd też w przypisach będą pojawiały się tytuły cytowanych opowiadań, wydanych pod wspólnym tytułem.

${ }^{49}$ Id em: Nie obeschnięte ścieżki. W: Ludzie spod miedzy..., s. 91.

${ }^{50}$ Zob. D. Niczyporuk: Czas i przestrzeń w światopogladzie mieszkańców wsi. Lublin 2002, s. 110 .

${ }_{51}$ W. Dunarow ski: Nie obeschnięte... W: Ludzie spod miedzy..., s. 91.

${ }^{52}$ Id em: Brzegi jasnego dnia. W: Ludzie spod miedzy..., s. 57.

${ }^{53}$ Zob. D. Niczyporuk: Czas i przestrzeń..., s. 118. 
du mieszkańców wsi przekonująco brzmią słowa Danuty Niczyporuk, dlatego warto je tutaj przywołać:

Szczególne miejsce w systemie społeczno-kulturowym wsi polskiej do końca XIX wieku zajmowała ziemia jako podstawowa kategoria aksjologiczna. Stanowiła ona miejsce zamieszkania, warsztat pracy, źródło utrzymania, trwały czynnik produkcji. Dlatego ziemia i gospodarstwo były wartościami autotelicznymi podporządkowującymi wszystkie inne wartości ${ }^{54}$.

W koncepcji waloryzacji przestrzeni zamieszkiwanej przez człowieka okresu międzywojnia można wyodrębnić dwa kontrastujące z sobą poglądy: człowiek miasta — jest panem siebie i własnej aktywności; mieszkaniec wsi niewolnikiem przyrody i świata. Koresponduje z nimi wypowiedź przedstawicielki inteligencji Oleksówny, z autopsji znającej kulturę oraz uwarunkowania podgórskich terenów pierwszej połowy XX wieku:

Pogląd na świat Żmiącan jest taki, jak większości chłopów polskich. Można by nazwać ten pogląd teocentrycznym w przeciwieństwie do ludzi miasta, których cechuje egocentryzm. Człowiek miasta wierzy w siły ludzkie, bo otaczają go dzieła rozumu ludzkiego i rąk ludzkich, A sam ma tylko to, co zdobędzie własną pracą. Człowieka zaś wsi otaczają dzieła rąk Boskich; ma całe życie do czynienia z przyrodą, której nie da rady ujarzmić - w przeciwieństwie do mieszkańca miasta, który czuje się jej panem. Gospodarz wie dobrze, że może strasznie ciężko pracować i mieć ładne urodzaje, a gdy przyjdzie grad - stłucze mu wszystko [...]. Susza, słota, mróz, woda i ogień uczą go, jak słaby jest człowiek ze swoim rozumem i ze swoimi rękami do pracy. Wie też, że jutro jest gospodarzem, jutro może być „dziadem” 55 .

W obliczu prezentowanych stanowisk nie dziwi postrzeganie kontaktu środowiska wiejskiego z ,miastowymi”, który traktowano w międzywojniu jako drogę do awansu społecznego. O mieszkańcach wiosek, którzy mieli na tyle szczęścia i odwagi, by podjąć się pracy zarobkowej w obcym miejscu, mówiło

${ }^{54}$ Ibidem, s. 103.

${ }^{55}$ Od Ujanowic do Laskowej. Przeszłość i współczesność. Oprac. M. Sromek. Ujanowice 2001, s. 91. Warto dodać, że Oleksówna nie była obojętną osobą w życiu Dunarowskiego. Przyjaźnili się, prowadzili korespondencję, a za prototyp Oleksówny uważa się bohaterkę opowiadania Dunarowskiego pt. Co z ciebie będzie, dziewczyno? opublikowanego w zbiorze: W. Dunarowski: Ciężar rąk. Warszawa 1949, s. 201-205. Zob. też K.M. Pławecka: Świat wartości Zofii Oleksówny - (nie)zwyczajnej polonistki. „Rocznik Sądecki”. T. XLV. Red. J. Leśniak, L. Migrała. Nowy Sącz 2017, s. 125-126. 
się tylko dobrze, traktowało z szacunkiem (,poszczęściło się ciotce”) i „świątobliwą powagą", tak jak Mańcię, służącą limanowskiego radcy. Powrót z Limanowej do rodzinnej wsi stanowił w międzywojniu ważne wydarzenie społeczne, rodzinne, a nawet indywidualne, co nie umknęło uwadze Dunarowskiego:

Oprócz przysmaków i wielu innych podarków [Mańcia - K.P.] wnosiła także autorytet, przeciw któremu nikt nie odważył się wystąpić. Starszej kobiecie, z miejska ubranej, po miejsku gadającej, było z tym wielce do twarzy $^{56}$.

Nie „osiągały” upragnionego awansu społecznego osoby wykształcone, powracające po ukończeniu szkół do rodzimej miejscowości. Zawieszone pomiędzy miastem a wsią, często borykały się z rzeczywistością społeczną kraju, w której dla wykształconych dzieci chłopskich nie było pracy, dlatego też zmuszone sytuacją, wracały na wieś, narażając się na pretensje rodziców i lekceważenie środowiska ${ }^{57}$. Jak objaśnić nieprzychylność najbliższych? Trzeba zaznaczyć, że kształcenie wiejskich dzieci wiązało się zazwyczaj z trudami i wyrzeczeniami całej rodziny, a traktowane było jako pewien rodzaj „inwestycji”, która po latach ma procentować. Z sytuacją wiejskiej młodzieży ambitnej wyraźnie sympatyzował autor, zapewne dlatego, że sam przeszedł niełatwą drogę edukacyjną „spod miedzy” w świat. W Bezpłatnej praktykantce zarejestrował urywaną płaczem rozmowę między córką a steranym już życiem ojcem. Młodziutka Zosia, pomimo ukończonych szkół i zdobytych kwalifikacji nauczycielskich, bezskutecznie poszukiwała posady i była wciąż „,na utrzymaniu” rodziny. Smutny los młodzieży wiejskiej w pełni ilustruje następujący fragment opowiadania:

Z tego mamrotania wyszło wreszcie, że on zrobił swoje: łożył koszta na te szkoły, sam nie dojadł a posyłał, nawet długu narobił. Lecz nie wymawia, broń Boże! Tylko, że już więcej nic zrobić nie jest w stanie. Sam nic nie ma. Właśnie pocieszał się, że jak Zośka zostanie nauczycielką, może czasem choć na tytoń coś przyśle. Może sobie przypomni o starym ojcu. I o tym, jak to nie dojadał, skąpił na wszystkim, byle ją przepchać przez te szkoły ${ }^{58}$.

Wypowiedź ojca przepełnia gorycz dyktowana nierównościami społecznymi na początku XX wieku, co potwierdza kolejny cytat:

\footnotetext{
${ }^{56}$ W. Dunarow ski: Zapajęczone katy. W: Ludzie spod miedzy..., s. 140—141.

${ }^{57}$ Zob. A. Borycki: O pisarstwie..., s. 260.

${ }^{58}$ W. Dunarow ski: Bezpłatna praktykantka. W: Ludzie spod miedzy..., s. 79.
} 
— Daliby ci posadę, żebyś była ze ślachty! Dla chłopa nigdy nic nie ma ino ten gnój! Złakreć jedna! Zawdy tak bywało. Zawdy wydziorstwo i tumanienie, zawdy... 59

Uwarunkowania społeczne wyznaczały ostre granice między mieszkańcami miast i wsi. Należy je łączyć z dysproporcjami materialnymi i ogromnymi spustoszeniami dokonanymi na ziemi limanowskiej podczas działań prowadzonych w czasie pierwszej wojny światowej. Współczesny badacz socjologii, znawca dziejów Limanowszczyzny, tak oto uzasadnia biedę i przeciwności losu, z którymi borykała się ludność na terenach wiejskich:

Dość, że przed wojną tereny te były ubogie, bo ludność miejscowa utrzymywała się tylko z rolnictwa, to działania wojenne pogłębiły tylko biedę miejscowej ludności. Rodziny przymierały głodem, a tzw. „przednówek” był symbolem niedostatku mieszkańców tego terenu. Ponadto choroby zakaźne, takie jak: gruźlica, jaglica, szkarlatyna, a także grypa dziesiątkowały miejscową ludność ${ }^{60}$.

Kogóż dzisiaj nie wzruszy historia ambitnego ucznia Wacka, który wiedział, że „musi odrobić za cały rok [...] po rocznym leniuchowaniu”, dlatego też pomagał rodzicom w okresie wakacji (również w niedziele), podczas najcięższych prac polowych. Pomimo wysiłku i wielu wyrzeczeń musiał jednak zrezygnować z zakupu butów, ponieważ wszystkie zarobione pieniądze przeznaczono na spłatę gruntów („Przynajmniej grunt nie pójdzie na licytację. Ratę jednak trzeba zapłacić. Nic nie pomoże. A Wacek musi chwilowo zrezygnować z butów"!) ${ }^{61}$. Rodzinna wieś z ciężkimi, fizycznymi pracami, jest mało atrakcyjnym miejscem do spędzania wakacji, stąd też uczeń Wacek ma świadomość, że bardziej zaimponuje rówieśnikom, gdy po powrocie do szkoły wymyśli „na poczekaniu [...] bajecznie kolorowe wakacje”. Rodzinne strony niewątpliwie budzą w młodym człowieku poczucie wstydu, który wynika właśnie z biedy i nędznych warunków życia na wsi, niekiedy urągających ludzkiej godności...

\footnotetext{
${ }^{59}$ Ibidem.

${ }^{60}$ W. Kołodziej: Kamionka Mała. Wieś powiatu limanowskiego. Toruń 2004, s. 149. Należy zaznaczyć, że autor wymienionej pracy podjął się trudu napisania monografii rodzinnej miejscowości, co uzasadniał we Wstępie: „Na podjęcie tej decyzji złożyły się dwa czynniki: pierwszy to, że uczuciowo związany jest $\mathrm{z}$ tą wsią, drugi - że z wykształcenia jest historykiem — politologiem i przedmiotem jego zainteresowania są problemy dotyczące zmian, jakie dokonały się w jego środowisku" (s. 5). Prezentowana wypowiedź zasługuje na uwagę z perspektywy badań nad rolą miejsca w życiu człowieka i pokazuje, że osoba wykształcona, tej miary, co profesor wyższej krakowskiej uczelni, chce pamiętać i ocalić od zapomnienia świat małej wioski, swojski świat. Pragnę w tym miejscu podziękować Profesorowi — Rodakowi — za inspiracje badawcze oraz interesujące rozmowy na temat kultury Limanowszczyzny.
}

${ }^{61}$ W. Dunarow ski: Nad Dunajcem pachnie siano. W: Ludzie spod miedzy..., s. 55. 
Obraz nędzy i trudno dostępnych terenów podgórskich jeszcze bardziej wyostrza się, jeśli weźmiemy pod uwagę brak obuwia. Niełatwo dzisiaj wyobrazić sobie sytuację, w której przedmioty codziennego użytku „szanuje się”, traktuje jak towar luksusowy, dostępny od święta. Często jedna para obuwia służyła wielu domownikom, np. podczas wyprawy do kościoła ${ }^{62}$ albo przemieszczania się po stromych, przepastnych, niekiedy podmokłych terenach. Obraz strudzonego wędrowca utrwala wymowny fragment:

Do izby wtoczyły się ciężkie buty, obielone dwumilową drogą, uginające się pod brzemieniem spoconego postękiwania. Pod ścianą jękła spracowana ława, uciszona wymownym westchnieniem: - To ja już jestem z powrotem! Prawie nóg nie czuję! [...] Dopiero przy zetknięciu ziemi bosą stopą doznaje ulgi ${ }^{63}$.

Reasumując, prezentowany zbiór opowiadań Ludzie spod miedzy to niewątpliwie książka o wsi jako miejscu ważnym, chociaż niełatwym do życia w latach międzywojennych. Do walorów opowiadań Dunarowskiego zaliczyć trzeba doskonałą znajomość realiów życia rodzinnej okolicy we wszelkich jego przejawach i problemach mieszkańców wsi, wyrażanych za pomocą ich własnego języka. Jego twórczość — trzeba tutaj kolejny raz przyznać rację zaprzyjaźnionej z pisarzem Oleksównie - jest dokumentem językowym, pełnym typowo gwarowych powiedzonek, wyrażających pewną filozoficzną postawę. W korespondencji prywatnej zauważa ona: „U Ciebie góruje podejście psychologa i stąd najważniejsze przeżycia ludzkie a nie tylko chłopskie" ${ }^{64}$. Jej wypowiedź trafia w sedno recenzji krytyka literackiego, który także zastanawiał się nad siłą oddziaływania twórczości Dunarowskiego:

I nie wiadomo o co tu więcej chodzi: czy o te sprawy, czy o człowieka. Bo na jedno i drugie rzuca autor — gęsty snop światła. A oryginalność książki

${ }^{62}$ Znakomitym uzupełnieniem wiedzy na temat warunków życia, ubioru i zewnętrznego wyglądu ludności podgórskiej może być opracowanie Jana Ligęzy, który m.in. pisze tak: „[Mieszkańcy Ujanowic - K.P.] całe lato chodzili boso, jedynie do kościoła w niedziele przywdziewali zimowe, duże buty z prostej skóry, o jednej podeszwie, z wywijanemi cholewami, całe szyte. Do butów wkładali wiechcie słomiane i nogę przed włożeniem do buta obwijali słomą »okrączką«". J. Ligęza: Ujanowice. Wieś powiatu limanowskiego (zapiski z roku 1905). „Prace Komisji Etnograficznej Polskiej Akademii Umiejętności” 1928, nr 6, s. 24. W innym miejscu sugeruje, że buty stanowią wyróżnik w obrębie grup etnicznych, gdy ze znawstwem konkluduje: „Ujanowiany przyznają się, że są Lachami. Dzielą mieszkańców powiatu limanowskiego na górali i Lachów. Góralami nazywamy tych, którzy noszą kierpce, Lachami, którzy noszą buty”. Ibidem, s. 23. Podkr. - K.P.

${ }^{63}$ W. Dunarow ski: W sadzie. W: Ludzie spod miedzy..., s. 65.

${ }^{64}$ Listy Zofii Oleksówny do Władysława Dunarowskiego. Rabka, 29 IV 1963 r. [wydruk komputerowy]. 
polega na tym, że światło to pada z coraz innego miejsca i innego wzniesienia. I tak pada, że odsłania nie tylko coraz inne kwestie współczesnej wsi [...]. Ale, co najważniejsze, wdziera się do tajników duszy ludzkiej, by z prostej na pozór bryły „ludzi spod miedzy” wydrzeć splot tajemnic: by odsłonić świat uczuć... By odkryć człowieka ${ }^{65}$.

\section{Wnioski dydaktyczne}

Literatura Dunarowskiego, niczym fotografie, dobrze wpisuje się w niezwykle istotny proces utrwalania pamięci o małej ojczyźnie. W perspektywie przyjętej przez pisarza, bliskiej założeniom antropologii literackiej, najważniejsze jest jednostkowe doświadczenie człowieka. Jak we współczesnej szkole czytać opowiadania międzywojenne? W odpowiedzi na to pytanie posłużę się następującą podpowiedzią dydaktyczną:

Dużego znaczenia dla antropologicznego oddziaływania utworów na czytelnika nabiera $[\ldots]$ poznawcza funkcja literatury — powiadamiająca odbiorcę o przesłankach świata przedstawionego w dziele, o różnych sposobach bycia w nim człowieka [...]. Stąd też literaturę można rozumieć jako zwierciadło „w którym przegląda się ludzkość ubrana we wszystkie wytwory i przejawy kultury"66.

Trzeba tutaj zastrzec, że Dunarowskiego literacki obraz Limanowszczyzny, chociaż w dużej mierze pełen realizmu, jest jednak pewną odautorską propozycją, kreacją, w której wyjaskrawione zostały głód i niepewność jutra, a mieszkańcy przeludnionych wiosek przytłoczeni przez ciężar pracy i trudne warunki egzystencji. Uwarunkowania bytowe wywołują we współczesnym czytelniku współczucie dla bohaterów, połączone z pewnego rodzaju niedowierzaniem: jak w opisanym miejscu można było żyć i przetrwać w tak dramatycznych warunkach? Opisywana rzeczywistość międzywojenna nie jest dostępna doświadczeniu młodzieży XXI wieku, dlatego, jak sadzę, literacki portret człowieka krainy „kęp i nędzy”, zwłaszcza wśród młodych, niedoświadczonych ludzi może wzbudzać skrajne emocje i (co łatwo przewidzieć, aby pomóc młodemu odbiorcy) wiązać się z uczniowską niedoskonałością lektury. Wydaje się, że materiał literacki zainteresuje najbardziej „dojrzałych” czytelników (na IV etapie

\footnotetext{
${ }^{65}$ W. Dunarow ski: Ludzie spod miedzy. Warszawa 1939 [obwoluta].

${ }^{66}$ D. Łazarska: Osoba ucznia w świadomości studentów polonistyki..., s. 131-132.
} 
edukacyjnym) ${ }^{67}$, pragnących zgłębiać tajniki literatury skrywającej osobliwe historie poprzedników, losy osób, żyjących tutaj — niegdyś.

Umiejętność interpretowania ludzkiego doświadczenia dobrze wpisuje się w niezwykle ważne założenia metodyki polonistycznej ukierunkowanej na wychowawczy wymiar lektury. Cele tak zaprojektowanych działań można by sprowadzić — zgodnie z sugestią Zofii Budrewicz — do ważnego w życiu jednostki i społeczeństwa odkrywania:

[...] związku historii, narodu oraz pokolenia z pamięcią [które - K.P.] daje poczucie porządku i ciągłości. Celowość wysiłku pamiętania wiąże z uobecnianiem w teraźniejszości przeszłych wydarzeń, więc i ocalaniem ich przed trwałym zapomnieniem ${ }^{68}$.

Lektura Dunarowskiego współcześnie czytana stwarza ponadto okazje do wyrwania się z kompleksów albo tzw. mitów polskich i mitów ludowych. Interesująco pisał o nich Roch Sulima:

Inteligenci i artyści o ludowej genealogii, artyści w sensie, jaki temu pojęciu — nadał XX w., z antropologicznej refleksji nad kulturą wywodzą swoje dzieła. W zanurzeniu się w świat wiejskiego dzieciństwa [...] leczą swoje neurozy, kompleksy wykorzenienia, kłopoty z tożsamością,

ale też — jak wskazuje antropolog — jest to literatura „„»nowej wrażliwości«, literatura dialogu" ${ }^{\prime \prime}$.

Przywołany kontekst pozwala dostrzec w kulturowym dziedzictwie literackim obraz dramatycznego doświadczenia Lachów, zamieszkujących w przeszłości obszar ziemi limanowskiej i okolic; świat Polaków, który był i jest częścią małej-wielkiej historii Polski, naszym wspólnym światem.

Z czytaniem miejsca - Limanowszczyzny — wiąże się jeszcze rekonstruowanie śladów i świadectw ,dowodów dokumentalnych”70, prowadzących dalej do uchwycenia różnic między obrazami życia poszczególnych warstw społecz-

${ }^{67}$ Zob. też M. Jędrychowska et al.: To lubię. Podręcznik do języka polskiego dla I klasy — liceum ogólnokształcące, liceum profilowane i technikum. Kształcenie kulturowo-literackie. Kraków 2002. Część druga podręcznika: Trzeba wiedzieć, z czego się wyrasta zawiera ciekawe materiały dydaktyczne i liczne teksty źródłowe (m.in.: Wielki świat mojej małej wsi, fragment rozmowy z Wiesławem Myśliwskim), przydatne podczas realizacji tematyki czytania miejsca (s. 83-136).

68 Z. Budrewicz: Miejsce i pamięć w polonistycznej edukacji regionalnej. W: Krajobrazy pamięci — pamięć krajobrazu. Red. Z. Budrewicz, M. Sienko. Kraków 2014, s. 247-248.

69 Zob. R. Sulima: Głosy tradycji..., s. 101.

70 Z. Budrewicz: Miejsce i pamięć w polonistycznej edukacji regionalnej. W: Krajobrazy pamięci..., s. 240 . 
nych, funkcjonujących przed wojną obok siebie. Takie możliwości stwarzają zachowane do dzisiaj międzywojenne fotografie Klementyny Zubrzyckiej-Bączkowskiej ${ }^{71}$. Warto przyjrzeć się im z bliska, ponieważ mogą otwierać czytelnika na postrzeganie różnych obrazów człowieka w dokumentach kultury oraz na portretowanie $w$ ich świetle siebie samego.

Odkrywając związki człowieka z miejscem dzięki lekturze świadectw, odwołam się na koniec do znanej w dydaktyce polonistycznej roli literatury jako źródła mądrości. Można z niego „zaczerpnąć” (a następnie rozważyć, świadomie podejmując ryzyko sygnalizowane już na początku wywodu) w holu Miejskiej Biblioteki Publicznej w Limanowej im. Władysława Dunarowskiego, gdzie na pamiątkowej, drewnianej tablicy „wyciśnięto" ponadczasowe przesłanie patrona książnicy, odwołujące się zarówno do rozumu, jak i do serca czytelników: „Radio, telewizja, gazety spełniają rolę łącznika za światem... Dla książki pozostaje rola najbardziej specyficzna: penetracja w świat myśli ludzkiej i ludzkich wzruszeń".

\section{Bibliografia}

Augé M.: Nie-miejsca. Wprowadzenie do antropologii hipernowoczesności. Tłum. R. Chymkowski. Przedmowa W.J. Burszta. Warszawa 2012.

Borycki A.: O pisarstwie Władysława Dunarowskiego. W: Nad Dunajcem pachnie siano. Wybór opowiadań. Gdańsk-Bydgoszcz 1978.

Buczyńska-Garewicz H.: Miejsca, strony, okolice. Przyczynek do fenomenologii przestrzeni. Kraków 2006.

Budrewicz Z.: Miejsce i pamięć w polonistycznej edukacji regionalnej. W: Krajobrazy pamięcipamięć krajobrazu. Red. Z. Budrewicz, M. Sienko. Kraków 2014.

Budrewicz Z.: Tradycje $i$ współczesność regionalizmu edukacji polonistycznej. W: Region i edukacja. Literatura - kultura - społeczeństwo. Red. Z. Budrewicz, M. Kania. Kraków 2006.

Burkot S.: Pochwała małych ojczyzn i małych historii. „Małopolska”. T. 7. Red. E. Chudziński. Kraków 2005.

Burkot S.: Proza powojenna 1945-1987. Warszawa 1991.

Burszta W.J.: Samotność w świecie nadmiaru. Przedmowa do wydania polskiego. W: M. Augé: Nie-miejsca. Wprowadzenie do antropologii hipernowoczesności. Tłum. R. Chymkowski. Przedmowa W.J. Burszta. Warszawa 2012.

${ }^{71}$ Zob. K.M. Pławecka: Fotografie Klementyny Zubrzyckiej-Baczkowskiej jako do-świadczenie regionu (na przyktadzie wystawy — „Światto-czułe świadectwo. Skarb z Limanowej). W: Czytanie Dwudziestolecia IV. T. 1. Red. E. Wróbel, J. Warońska. Częstochowa 2016, s. 253-266. O ile literatura ukazuje przysłowiową biedę z nędzą, o tyle fotografia „,zapisuje światłem" świat bogatych limanowskich mieszczan. W tym sensie dokument literacki mocno kontrastuje ze zdjęciami pierwszej wykształconej farmaceutki, córki burmistrza Limanowej Klementyny Zubrzyckiej-Bączkowskiej i zaprasza uczniów do roli badaczy pożółkłych już nieco świadectw przeszłości. 
Bydgoski stownik biograficzny. T. 5. Red. J. Kutta. Bydgoszcz 1998.

Domańska E.: Mikrohistorie. Spotkania w międzyświatach. Poznań 2005.

Dunarowski W.: Ciężar rąk. Warszawa 1949.

Dunarowski W.: Ludzie spod miedzy. Warszawa 1939; Bydgoszcz 1987.

Dutka E.: Zapisywanie miejsca. Szkice o Ślasku w literaturze przełomu wieków XX i XXI. Katowice 2011.

Faron B.: Powrót do korzeni. Kraków 2000.

Faron B.: Władysław Orkan i Beskid Śląski. W: Wokót Władysława Orkana. Aspekty literackie, kulturowe i medialne. Red. B. Faron, współpraca A. Ogonowska. Kraków 2011.

Górski A.: Na nowym progu. Warszawa 1918.

Jędrychowska M. et al.: To lubię. Podręcznik do języka polskiego dla I klasy — liceum ogólnoksztatcace, liceum profilowane i technikum. Kształcenie kulturowo-literackie. Kraków 2002.

Jędrzyński Z.: Władysława Dunarowskiego pisarskie przesłanie. „Gazeta Pomorska” 1988, nr 11. Kołodziej W.: Kamionka Mała. Wieś powiatu limanowskiego. Torun 2004.

Kossakowska-Jarosz K.: Opolszczyzna prywatna w pisarskim doświadczeniu Jana Goczoła. W: Geografia wyobrażona regionu. Literackie figury przestrzeni. Red. D. Kalinowski, M. Mikołajczak, A. Kuik-Kalinowska. Kraków 2014.

Kuźma E.: Regionalizm. W: Stownik literatury polskiej XX wieku. Red. A. Brodzka et al. Wrocław-Warszawa 1992.

Kwiek-Osiowska J.: Ziemio moja sądecka... Antologia poezji i prozy. Kraków 1991.

Lewicka M.: Psychologia miejsca. Warszawa 2012.

Ligęza J.: Ujanowice. Wieś powiatu limanowskiego (zapiski z roku 1905). „Prace Komisji Etnograficznej Polskiej Akademii Umiejętności”. Kraków 1928, nr 9.

Literatura polska XX wieku. Przewodnik encyklopedyczny. T. 1. Red. A. Hutnikiewicz, A. Lam. Warszawa 2000.

Łazarska D.: Osoba ucznia w świadomości studentów polonistyki. O zwiazku literaturoznawstwa $z$ dydaktyką. Kraków 2015.

Mrozek Z.: Władysław Dunarowski. „Fakty” 1986, nr 3.

Myrdzik B.: Zrozumieć siebie i świat. Szkice i studia o edukacji polonistycznej. Lublin 2006.

Niczyporuk D.: Czas i przestrzeń w światopoglądzie mieszkańców wsi. Lublin 2002.

Nowicka G.: Wnikanie w los człowieka. „Gazeta Pomorska” 1983, nr 23.

Nycz R.: Od teorii nowoczesnej do poetyki doświadczenia. W: Kulturowa teoria literatury 2. Poetyki, problematyki, interpretacje. Red. T. Walas, R. Nycz. Kraków 2012.

Od Ujanowic do Laskowej. Przeszłość i współczesność. Oprac. M. Sromek. Ujanowice 2001.

Orkan W.: Komornicy i opowiadania wybrane. Wyboru dokonał i posłowiem opatrzył B. Faron. Warszawa 1975.

Pieniążek M.: Uczeń jako aktor kulturowy. Polonistyka szkolna w warunkach płynnej nowoczesności. Kraków 2013.

Piramowicz G.: Powinności nauczyciela... W: Komisja Edukacji Narodowej. Wybór źródet. Zebrał i oprac. S. Tync. Wrocław 1954.

Pławecka K.: Limanowa $w$ świetle międzywojennej prasy nowosadeckiej. „Rocznik Sądecki”. T. XXXII. Red. F. Kiryk. Nowy Sącz 2004.

Pławecka K.: „Pomiędzy kultura a ziemia”. Od świata globalnego do lokalnego na przyktadzie literatury ,stad”. „Annales Universitatis Paedagogicae Cracoviensis. Studia ad Didacticam Litterarum Polonarum et Linguae Polonae Pertinentia VIII”. Red. M. Szymańska, M. Pieniążek. Kraków 2017.

Pławecka K.: Przygotowanie polonistyczne uczniów wiejskich gimnazjów w perspektywie dalszego kształcenia (na przykładzie gminy Laskowa). Kraków 2013. 
Pławecka K.: Recenzja książki Bolesława Farona „Powrót do korzeni”. „Nowa Polszczyzna” 2001.

Pławecka K.M.: Fotografie Klementyny Zubrzyckiej-Bączkowskiej jako do-świadczenie regionu (na przykładzie wystawy —,,Światto-czułe świadectwo. Skarb z Limanowej). W: Czytanie Dwudziestolecia IV. T. 1. Red. E. Wróbel, J. Warońska. Częstochowa 2016.

Pławecka K.M.: Świat wartości Zofii Oleksówny - (nie)zwyczajnej polonistki. „Rocznik Sądecki”. T. XLV. Red. J. Leśniak, L. Migrała. Nowy Sącz 2017.

Polakowski J.: Idee dydaktyki podmiotowej $w$ podstawowych problemach ksztatcenia literackiego (nurt antropocentryczno-kulturowy). W: Podmiotowy wymiar szkolnej polonistyki. Red. Z. Uryga. Kraków 1998.

Regionalizm w nauczaniu języka polskiego w szkole średniej. Red. E. Rosner. Warszawa 1975.

Rybicka E.: Geopoetyka. Przestrzeń i miejsce we wspótczesnych teoriach i praktykach literackich. Kraków 2004.

Saryusz-Wolska M.: Spotkania czasu z miejscem. Studia o pamięci i miastach. Fotografie J. Hohmuth. Warszawa 2011.

Sporek P.: Pojęcie sceny w przestrzeni aksjologicznej dialogu. Edukacyjny wymiar refleksji filozoficznej Józefa Tischnera. „Annales Universitatis Cracoviensis. Studia ad Didacticam Litterarum Polonarum et Lingua Polonae Pertinentia VI”. Red. P. Kołodziej, J. Waligóra. T. 6. Kraków 2015.

Sulima R.: Głosy tradycji. Warszawa 2011.

Tischner J.: Filozofia dramatu. Kraków 2012.

Wystapienie Ministra Oświaty i Wychowania - prof. dra hab. Bolesława Farona. „Polonistyka” 1983, nr 7.

\section{Materiały niepublikowane}

Jurkiewicz E.: Literacki świat Władysława Dunarowskiego. Praca magisterska napisana na seminarium literatury polskiej pod kierunkiem dra Zdzisława Mrozka. Wyższa Szkoła Pedagogiczna w Bydgoszczy. Bydgoszcz 1988.

Listy Zofii Oleksówny do Władysława Dunarowskiego. Rabka, 29 IV 1963 r.; Nowy Sącz, 12 XI $1965 \mathrm{r}$.

Matras H.: Dunarowski Władystaw, 21 III 1982 roku.

\section{Źródła internetowe}

www.mapakultury.pl.

www.wyrwanezkontekstu.pl/literatura/kochamy-wciaz-za-malo-i-stale-za-pozno-cytaty-z-ks-janatwardowskiego/. 